\title{
Rethinking the quality of the connection between school and city according to a sociability analysis of schools of the Timurid, Safavid and Ghajar eras in Iran
}

\author{
H. Motedayen ${ }^{1}$, M. Ahangari ${ }^{2} \&$ K. Chenari ${ }^{3}$ \\ ${ }^{1}$ Fine Arts Faculty, University of Tehran, Iran \\ ${ }^{2}$ University of Tehran, Iran \\ ${ }^{3}$ IT Department of Shahrvand Chain Store, Iran
}

\begin{abstract}
The following paper is a result of a field and librarian study in recognition of the connection between school and city in Iranian Islamic architecture and tries to find the different forms of these connections by analyzing the physical characteristics of the space of schools and finding their source. Thus, more than twelve structures from reputed eras of Timurid, Safavi and Ghajar were chosen. Then by studying the situation of the country in the specific era, the presence or absence and the location of a collective space for students and people in schools were studied. In this paper, which is applied and developmental, comparisons show that in the schools of those eras of Iran there was a view of connecting to city and the foundation of this connection was considered. Thus, dissimilar incorporation of social space with a school shows that there is no uniform approach to all engagements. It seems that the basis of such difference should be discovered in the difference between the policies of each government. Accommodation of analysis shows three general interpretations from the meaning of connection. It is best to arrange and analyze different connection qualities to clearly understand these interpretations. It can be concluded from the analysis that knowing that the sociability of schools plays a key role in explaining the position of this space in each era, it seems to assume that "although schools' structures of traditional Islamic eras of Iran were affected by their performance, they consequently reflect beliefs of rulers" is defendable.

Keywords: Islamic architecture, schools, space creation, government, sociability.
\end{abstract}




\section{Introduction}

What is rarely seen these days in Iranian schools is the possibility of meaningful interactions of students with each other and also with the people of the neighborhood. The root of the problem must be seen in educational policies of today's Iran and the lack of appropriate basis for this behavior. By ignoring the importance of interactions, the articulation between school and neighborhood (center of interactions for students and people) is lost and functions of sociable spaces inside schools have changed. Hence, superficiality of children and teenagers' education can be observed. The traditional approach to education in Iran, by the way, considered school as a part of students' life, and the school was a place for development; which is the fact that modern education is seeking as its goal. Such a link between these two views, creates an opportunity for the revision of the physical properties of the traditional schools in Iran in order to resuscitate them. It is a good logical process to analyze schools in different periods of Iranian history. Given the time limitations of this study, through different historical periods, Timurid, Safavid and Ghajar were selected.

This paper emphasizes the presence or absence and location of public space of students and people in schools of Islamic era. Locating and examining the relationship between spaces by visiting the monuments and reviewing the existing maps of buildings and their history are parts of the study.

\section{Hypothesis and research questions}

The study of Timurid architecture shows significant structural changes in schools in that era. This evolution is contemporaneous with the addition of common urban - school areas in the entrance of the building and strengthens official school attendance of people. Of course continuation of such a relation between school and city can be investigated in the Safavid and Ghajar eras. But contemplation in schools' structures shows a dissimilar incorporation of public space with schools in different eras in a way that this difference and the resulting obscurity forces us to investigate the relations between students and people. Thus the strengths of a school's tendency towards city becomes interesting. If the relationship is the same, why are multiple incorporations set in school structures of these periods and if not, what is the cause of these differences? It seems that operational requirements of each government has a significant impact in the creation of these interactions and it means that diversity in incorporation of these two spaces creates different social, political and economic properties of each era.

In this regard, the following paper tries to understand the relation between city and school in the mentioned eras and fundamental questions can be asked:

1- What quality is observed in incorporation of public sections with schools in each era?

2- What interpretation of the concept of relationship does each of these methods support?

3- How can one examine the relation between companionship of school and city and operational requirements of governments? 


\section{Literature and the related conducted studies}

About the background of the research it can be mentioned that architecture of Islamic schools has been seen as an important factor by various groups.

Some of the documentation of this paper has historical roots in the writings of orientalists and historians. Among those, some like Della Valle (1586-1652), Chardin (1643-1713) and Campfer (1651-1716) are more famous. However, in this regard considering memories of Iranians like Zill al-Sultan (1850-1918) can be useful for studying Ghajar period's architecture. In such writings, economic and social conditions of people, the atmosphere of the cities and some important places at the time are depicted. The matching hypothesis could indeed be fruitful.

Other used resources for the study are books about studies of Islamic architecture, for example, Hillenbrand [1] in the book called "Islamic architecture" studies schools and their architecture in Muslim lands and Pirnia [2], devoted some parts of "Cognitive of Iranian architecture style" to studies about Iran's schools and their main spaces.

In this regard, books in the form of an encyclopedia have been developed. Mollazade and Mohammadi [3] have written "Encyclopedia of Schools and Religious Buildings" in which all the schools of Islamic periods in Iran have been mentioned. Cultural Heritage's "Ganjnameh" [4] can also be categorized in this respect. In these works, maps of schools and a short description about them are gathered.

On the other hand, some works of Iranian and non-Iranian specialists about studying the structure of schools in Iran's Islamic era are available. For instance, Donald N. Wilber's "Islamic architecture in Iran and Turan" [5] and "Timurid architecture in Khorasan" by Bernard O'Kane [6] can be mentioned. To study Timurid schools with a view to assessing the present case, the writings of the historians can be useful. Books like "The evolution of schools in Iran" written by Alireza Sami-Azar [7] and also "Iranian school history from ancient times to the establishment of Dar-Al-fonon" by Hussein Soltanzadeh [8] can be useful for this study, hence some parts of the writings are mentioned later.

Sami Azar [7], compares school framework in contrast to the approaches of each measured period. For example in the Safavid period, the structure of education is shaped based on Government - Religious policies. The function of public education for schools is defined in this way and influences its architecture. On the other hand, Soltanzadeh [8] describes the economic, political and social situation and explains their relation with quantity of schools. The location of the buildings in the city is examined next. For example, the formation of schools in the vicinity of mosques is mentioned and sees it as functional harmony between these spaces. In fact, he explains the connection between school and city following the function of schools and believes that the introduction of chapel and retire rooms in schools or school-mosque appearance are the results of this articulation operation. But in his writings, there is not sufficient analysis about quality of relation between school and society in different periods of time.

However, this paper, sees the opposition of framework and function undeniable but examines this moderately. In other words, the definition of public 
functions in the schools (such as public prayer or public teacher) is toward the policies of each government to establish the interaction of people and students. Thus, the assumption is proposed that the style and quality of the relationship between the school and the city will vary according to the requirements of each state.

\section{Description of sociability of schools}

Sociability of schools is a feature in the quality of architectural space that brings the users together, but the purpose of the theme in this paper is the examination of social interaction of schools regarding city.

Pirnia [2] considers schools as the most important public buildings in the city after mosques. In schools, as well as other buildings a range from the individual to the collective territory can be seen; from the chambers in which local seminary students lived, the small verandas that made conversation possible and the other verandas which were the main place of teaching [2] and as a result, more people participated in the discussion. By studying schools of Iran's Islamic era it can be concluded that most of them had spaces which in addition to the students, everyone enjoyed them and thus social cohesion between these groups was reinforced. The presence of such places in schools leads us to the connection of school and city and the method of its location setting shows the quality of connection.

\section{Sociability of schools in the Islamic era}

\subsection{Sociability of schools in Timurid period}

With the Timurid, a new power emerged in Central Asia and the distribution of previous periods decreased by some extent and an economic boom happened [9]. The Timurid rulers tried to gain the support of scientists and grandee sometimes because of interest and sometimes because of enthusiasm. Hence, the school was developed as the biggest institute of religious sciences [5] so that Hillenbrand [1] sees Timurid as the golden age of Iran's schools. Development of schools especially in government centrals can be observed in this period. It is worth saying that financial support of schools was done by the court or officials.

Dome structure with different uses can be seen in schools of this era. Khargerd School of Ghiasieh, has four domes on the four corners and domes on both sides of the entrance porch are large and distinct. One of them has the function of prayer; of course not very accurate [10] that some people call it as mosques [9] and the other dome was hall of preaching. Both of the abovementioned parts are practical which In addition to students, the city also enjoyed it (O' Kane [6]). The combination of entrance and two adjacent domes is called "The entrance complex" and Wilber [5] sees it as one of special characteristics of the Timurid schools. In Ghiasieh school, the entrance complex is completely independent from the building, because access to two of its domes is just from the inside entrance porch and there is no other direct way from mosque or hall of 
preaching to the courtyard's rooms. So connection and separation between school and city can be seen here.

Breakdown of the territory in this way can be resulted from social and economic policies of that period. The creator of Ghiasieh, Minister of Shahrukh Mirza, built it in a small village and in a position that there were no mosques around it. So it is not unreasonable that the mosque and the school's public preaching hall were devoted to other people in order to create an alternative to this application. On the other hand, because of the relative economic wealth, Ghiasieh's endowments were extended across a wide Khorasan so that after spending for school, a considerable sum was left for to the family of the founder. So in order to run the school, there were no need for public donations and mixing the school with the city was no longer relevant. Wilber [5] also states that in the Timurid period, there was no tendency toward building schools in people's passageway. In fact, such relationship between students and people can be seen in many Timorese schools which their architect was Qavam Al-Din Shirazi.

O'Kane [6] sees the entrance complex as Qavam Al-Din's idea that was backed by the policies of that era.

Superior schools can be seen in non-capital cities in this period. Bukhara was an important economic city which most of its buildings have been built with the taxes of the people. Ulug Beg schools in this city is an example of pair schools [1] And it also can be compared with Ghiasieh. This school has a mosque and the hall of preachers for public use. But in terms of spatial resolution it is slightly different from the plan of Ghiasieh, so that one of the domed halls has direct access to other spaces of school. The same happens in the school structure of Ulugh Beg in Samarkand (the same age as Ulug Beg School in Bukhara). In fact, more flexibility in mixing the realm of scholars and people can be seen. Oakin [6] sees it as a tendency toward schools of sixteenth century and proposes that maybe this route was created by users later.

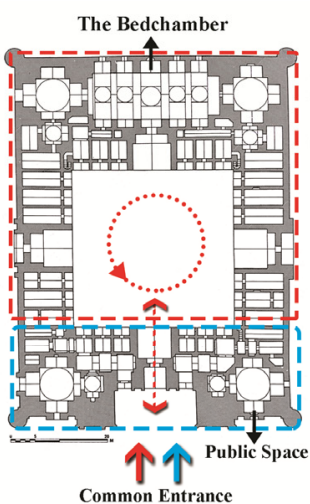

(a)

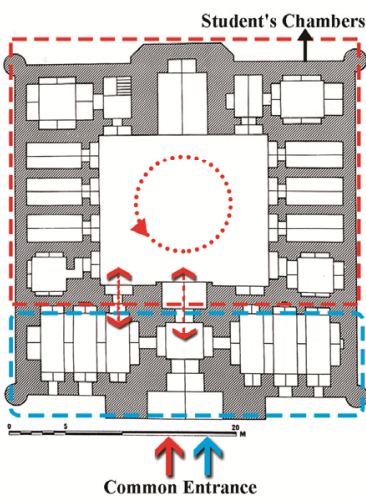

(b)

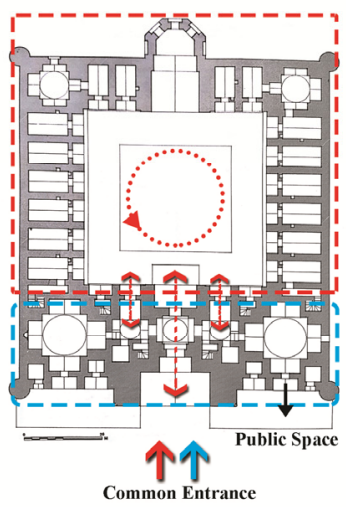

(c)

Figure 1: Comparing separation of public space in three school named Ulug Beg. (a) Ulug Beg in Samarkand [5], (b) Uluḡ Beg in Ghvj Divan [5] and (c) Ulug Beg in Bukhara [5]. 
Another difference of Ulugh Beg in Samarkand with Ghiasieh and Ulugh Beg of Bukhara is articulation account between the school and the city. This building was built in Rigestan Square and in the vicinity of the mosque and the monastery and thus provides a place for the Congregational Prayer. On the other hand, Wilber [5] sees the school as a university at the time being because of the variety of services. Accordingly, it is reasonable that adjacent domes of entrances be regarded as teaching application for people of the city and also the bedchamber of mosque continues inside the building and behind the southern porch.

Design of entrance complex can be seen in the Ulug Beg school in Ghvj Divan too (the public space of schools) which its application and spatial separation are similar to Ulug Beg in Bukhara.

\subsection{School and city connection methods in the Safavid era}

Although the pace importance of construction in the Safavid period almost prevented new occurrences in constructions, transformation of collocation of spaces, especially in schools can be seen comparing to Timurid era. To put it more clearly, architecture and urban design was changed in this period, which were resulted from elements of religious, social, economic and political progress made during this period.

During the Safavid kings wanted to form a Shiite-national state. Hence, policies of promoting Shia was taken to maintain national unity and strengthen state power [11]. Therefore, holding national celebrations and religious ceremonies took place while this events needed a suitable platform to happen. As a result, government took acts in relation to urban design such as building urban areas. On the other hand, schools were designed in such a way to be able to embrace the people, aiming to advance ideological support.

Different qualities about the relation between school and city can be observed in this era. Some Safavid schools were built in urban areas thereby protecting the relation of students and citizens. Ganjali Khan School in Kerman is an example which was built during the kingdom of Shah Abbas in the vicinity of the market square. So that travelers of caravansary were settled on the ground floor and first floor was devoted to living and teaching space of students. On the other hand, the two groups shared the input elements, garden and the mosque, and the students' communication with townspeople and foreign businessmen was the beating heart of the city. The quality of this unity is so much that it seemed the school was passing through people.

Studies show that most of schools in Safavid era had a public profile, but the space in the maps are drawn into the building comparing to Timurid schools. Soltani School or Chaharbagh School in Isfahan are good examples of this fact. Before analyzing companionship of spaces, we should examine the position of schools.

Chahar Bagh School coincided with the reign of Shah Sultan Hussein and its main facade is on the west side facing Caharbagh Street [3]. It is worth saying that this street is one the most important arteries if Isfahan in the Safavid era and like Naghsh-e-Jahan Square, it was a social context for national and religious ceremonies $[12,13]$. One of the inn's endowment (Madar-e-Shah Inn) was on 
the east side of the school, and on the other hand, Prinia [2] described the north side of the building: "Among the market, there is a pompous quadripartite with a large dome where the school entrance opens to it." From this description, it is clear that the merchants were invited to the school. This class of people had a close social and religious relationship with the scientists and scholars and they were the main operators of religious ceremonies in Safavid period of time [11]. Thus invitation of merchants to school had a purpose and their financial support could improve the relationship between them and schools. It can be argued that the political and religious purposes of the government have been achieved here.

However, as noted earlier, western and northern entrances of the building were open to the public and there is direct access from the mosque to the outside area; it recalls the Timurid school entrance complex. The obvious difference in comparing communicative qualities of schools in these eras is related to the separation of students' and people territories. To put it more clearly, the central courtyard of Timurid schools was a privacy place for specific users [5], while in most schools in Safavid era, people cross the school yard to gain access to the chapel. The cohesion between Chahar Bagh School and the city is so strong that the wrong policies of Ghajar era could not change it. These spaces are described in the notes of Pierre Loti [14], which coincided with the reign of Muzaffar AlDin Shah in Iran: "Since the school is open for Muslim people, they enjoy the coolness and shade, sitting or lying on the stone yard smoking hookah; mild burble can be heard everywhere ... people gathered in the mosque to discuss religious matters."

In the Safavid period, there were schools which were seen as only a residential space for their students. However, the type of their positioning beside the mosque's public application, provides the connection between city and school. Suleimanieh and Naserieh Schools in the vicinity of the mosque of Imam (Jame Abbasi) are in this category. Abbasi Mosque was designed as a public

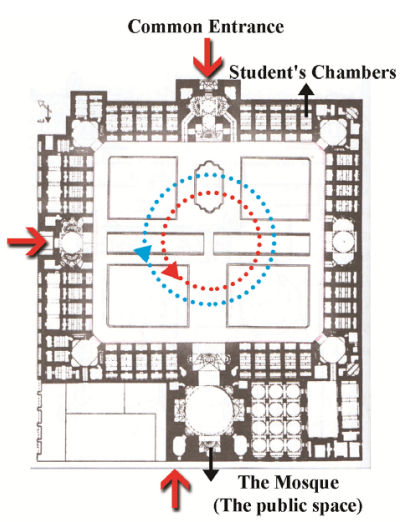

(a)

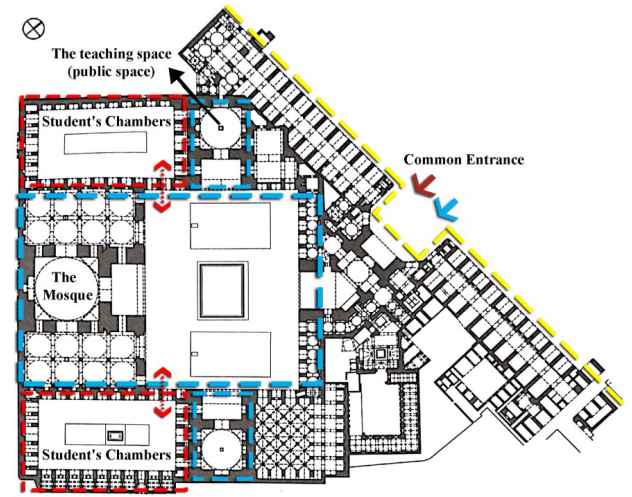

(b)

Figure 2: Examples of composition types in the Safavid era. (a) Chahar Bagh School [2] and (b) Suleimanieh School [4]. 
structure and an emphasis on Safavi's commitment to Shia Islam [11] and, in fact, holding public lectures to promote Shi' ism was considered as one of its main tasks. It is possible that all the spaces in two adjacent schools were devoted to students' residents and the inside space of mosque was the teaching space for this reason. In other words, the teaching space was placed inside the mosque and only the arcades sets the boundary between the school and the mosque.

The vicinity of mosque and school in the Ghajar era can be seen in abundance. As Hillenbrand [1] states: "Combining the two forms often (school and mosque) in Ghajar era in Iran has been employed in various institutions." Comparing the communicative qualities of this method with previous periods is as follows.

\subsection{The combination of school and city in the Ghajar era}

Although building school in Ghajar period, is similar in appearance with Safavid patterns, the separation of spaces is different from with it. In the course of designing schools we encounter designs that are in the vicinity of the mosque but the communication platform between seminary students and people is not provided as it was in Safavid. In dissecting the causes of the incident, one should consider the situation of the country. Researchers of the history of this period coincided with the decline of the country in economic, social and cultural aspects that are emerged as weaknesses in the administration of country [15]. Following this issue, government policies add on the severity of the problems, and thus the gap between government and people was obviously increased [16].

On the other hand, there were no royal kindness and endowed properties toward schools. As Eugene Aubin (1863-1931), the French ambassador, stated that during the Ghajar era, caravanserai and adjacent gardens of Chaharbagh were out of dedication of school and the free kitchen was dismantled [17]. With these explanations, economic crisis had weakened government even in the management of school affairs. So perhaps the emergence of such a quality in the relationship between the school and the city can be seen in the wake of the government's financial incentives to gather merchant worshipers' budget and providing school fees and clearing the demand for interaction between two spaces. Aubin [ibid] described the mosque of Shad and its teaching space and names merchants that paid school's fees. It is worth noting that a school and mosque were built by the name of Shah Abbas for religious motives of the government and its management was impossible without help of people. Of course, this type of financial aid to schools in the Ghajar period is so common that Najmi [18] everywhere in his writings calls it as Baqiat-Al-Salehat (good for the after death's life) and also mentions the role of Supreme clerics in securing scholars' expenses [ibid].

Another noteworthy aspect is the influence and power of the seminaries in protests. Relation between kings and people gradually fades, and this time scholars are intermediaries between the people and the government [19]. The government's unwillingness for relations between students and people (combining school and the city with Safavid style) is anticipated so that their interactions can be precisely monitored by the government. So although Ta'zieh 
and other religious ceremonies are held in schools, the government's monitoring decreases its quality to simple performance. In other words, the concept of communication that could be seen especially in Safavid schools of Chahar Bagh and Suleimanieh (as the Solidarity Center of students and people and the connector of people with government) is not reproduced here.

In fact, analyzing the structure of Tehran's mosque-school in Ghajar era approved this claim. Example of such buildings is Sheikh Abd-Al-Hossein.

Sheikh Abd-Al-Hossein mosque by combine school and mosque reminiscent of the Safavid school of Suleimanieh. But the combination of two structural space is different from it. The mosque as the linking factor of scholars and people is in the vicinity of schools but it is independent of it too. This time the amount of relationship between the school and the city has decreased to complete separation of entrances and even visual connection between them is disappeared so that students route to mosque's dome is just from the pre space of teaching place. Darb Yalan School in Kashan has the same manner and a corridor shaped space connects the mosque and school [3].

Another example of combined school and mosque in Tehran is seen in Sepahsaalaar. This school was established at the time of Naser-Al-Din Shah and it is often compared to Chahar Bagh School and the physical structure of the building is compared according to it. The school was built on the southeastern side of Baharestan Square, while the Ghajar fields, unlike the Safavid urban areas (such as Chahar Bagh Street and Naghs-e-Jahan Square) take a political aspect and Baharestan Square is no exception. The first difference between the two schools in terms of their position appears to be that they must have been based according to the policies of each period. Another difference is the layout of rooms and separation of public space. In this school, the dome and the nave is located on the ground floor and resting spaces are on the first floor. In fact they are separated from the ground by a belvedere. Therefore, there is no place for combination of passing routes of two class of people. In other words, even though people and students benefit from a common courtyard, Sepahsaalaar does not have the mood of Chahar Bagh.

Relationship between school and city can be found in other major cities of Ghajar era. For example, school of Sayyed in Isfahan continues Sepahsaalaar's way; public space and students' residential space are placed at two different levels but a belvedere also separate the two spaces and provides access to the courtyard for students.

One can see a new pattern in Isfahan which is the beginning of lots of combined methods. The structure of Aqa Bozorg School in Kashan is a good example. One of notable factors in this building is isolation of users' territory and combination of mosque and school at the same time. Here, is separated from the mosque under belvedere in front of the entrance and mezzanine is taller than the garden pit which rooms are formed around it [2]. In this way, the mosque is designed at a different level than school as a public space. So that people's access to seminary students' lives and studies is possible, but it does not mean the public freely commuting to school which is controlled. 


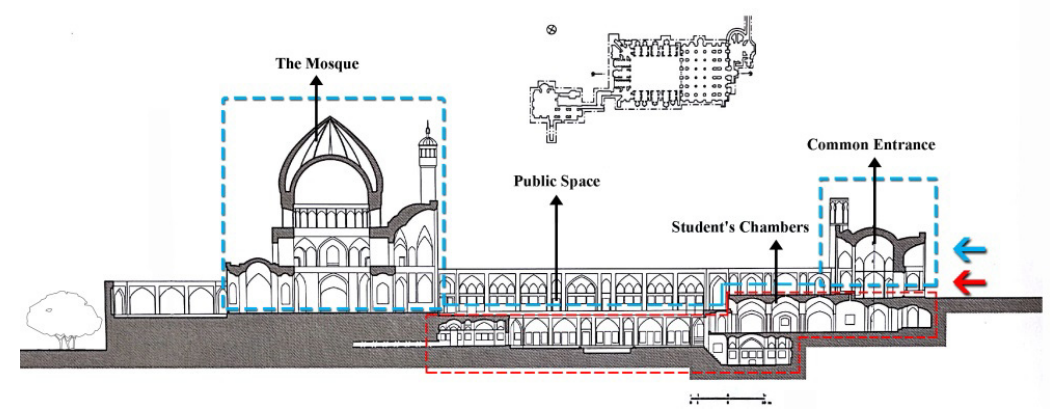

Figure 3: School and city at different levels in Aqa Bozorg [2].

\section{Physical framework's companionship in schools of different historical periods}

Earlier, the process of combination of school and city in different periods was discussed. In this section we try to summarize described features and categorize the way this relationship is reasonable. This categorization is done with ignoring type of public usages of schools, and is based on the passing routes of people in the building and considers the way of its combination with students' territory.

Table 1: Analysis of public space in schools of different historical periods.

\begin{tabular}{ll}
\hline Historical period & Schools' specification in terms of separation of public space \\
\hline Timurid & - schools as single structures \\
& - building schools in adjacent to squares according to the \\
& political or official importance of the square \\
& - considering entrance complexes including entrance and two \\
& public halls (articulation between school and city) \\
& - school's courtyard as students' specific territory \\
\hline Safavid & - building schools in a sociable context like squares or \\
& marketplace \\
& - using school's space for public ceremonies \\
\hline Ghajar & - building schools in different form from Safavid schools \\
& - increase in building structures as mosque - school \\
\hline
\end{tabular}

\section{Types of sociability of schools in the Islamic eras of Iran}

In different historical periods, according to the operational requirements, the integration of school and city has happened but there is no strict governing role for all of them. According to previous studies these categories can be discussed:

- First type: the combination of public space with the school in entrance intermediate layer

In this type of school, the body of interaction is an interface space between city and school and has been set in a way that one can access it from the entrance while the access from other spaces is not possible. 
- Second type: the combination of public space adjacent to the school in one building

Commuting to these complexes took place through common entrance of scholars and people. In this way, the public space is next to the school and aligned with it, while the teaching space is part of the mosque and other people can attend teaching sessions.

- Third type: the combination of public space inside school

In these schools, the public space is continued inside and the public can reach it by passing school yard and residential space. In some Example of this type, some rooms are considered on the other floor, but visual connection is established too.

- Fourth type: the combination of public space next to school by maintaining independence of the two buildings

In this type, school and mosque (public space) are two independent buildings but linked together in the same alignment and the same setup. In fact, entries, courtyards and other spaces are considered separately and there is no visual connection. While students say their prayers in the mosque and thus establish the relationship between the school and the city, although rarely.

- Fifth type: non-aligned combination of public space with the school

The connection of public space with school can be seen at the structure section in this type. This means that two spaces were built on two different levels, but their combining shows one building. In fact the public space is on the ground floor and residential rooms are adjacent to the belvedere (upper level) or around the garden pit (lower level).

Table 2: $\quad$ Types of composition in the era of the Timurid, Safavid and Qajar.

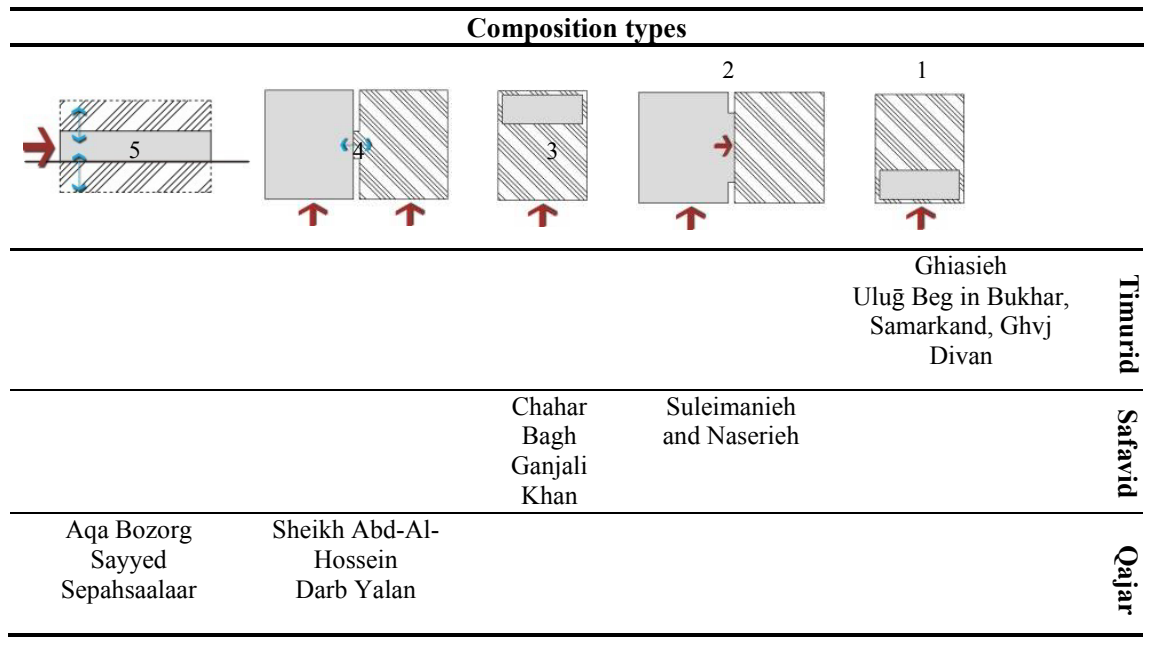

\section{Conclusion}

One way to understand the relationship between the school and the city is comparing it with the government's ideas, studies, analyses and comparing the 
spatial structure of schools in each period. There are three general interpretation of the concept of communication according to different methods of locating and space separation and thus contribute to the impact of various factors. This study showed that the combination of these two qualities can be categorized in five types which are as follows.

In the strong and Sunni government of Timurid, the country has relative wealth and kings tried to maintain power and control over people and show their interest in science and literature at the same time. Thus, in the structure of schools, public space remains between city and school (intermediate layer of entrance) so that separation of students' territory from people is obviously visible (first type).

After that, the rise of the influential Shia Safavid strengthen intellectual and cultural foundations. So it can be argued that such a correlation between the government and people is rarely found in other historical periods. Schools in Isfahan were places to exchange ideas and strengthen national unity and the multiple ways of companionship happened in them. The manner in which the school is adjacent and aligned with public space and defining the boundaries does not obscure the visual communication (second type). In some cases, the public space is drawn into school and passing routes of people are combined with students' living spaces and presence of common spaces improves the connection between these two spaces (third type).

On the other hand, in the Ghajar era, the crisis chaos inside people and weakness of the Kings, makes the gap between government and people more significant. The government that is afraid of riots, is reluctant to communicate among scholars and seminary students and people and also does not allocate funds for running schools. Thus, although there is still public application in schools, connection to the city appears paler than before and, as mentioned above, the level of relationship between people and school decreases from exchanging ideas to just an economic bound. Combining school and the city in this era does not deviate from two general approaches; some mosques are adjacent to schools but are independent from each other even at the entrance, courtyards and other spaces (fourth type). In other places, school and mosque create a single structure but are separated in two different levels. In this type public space is level with city and schools are on the upper level or lower level (fifth type).

From the above analysis it can be concluded that the combination of school and city at different historical periods does not use the same method. While the social recognition of schools has an important role in explaining the position of this space in different historical periods. So that the structure of the schools in the Safavid period (with certain policies of government), shows the unity between the school and the city better than other structures.

Thus, it seems that this assumption is untenable that although the schools of the Islamic era of Iran were affected by their performance, they represent the ideas of kings and requirements of that specific historical period. 


\section{References}

[1] Hillenbrand, Robert, Islamic architecture: form, function, and meaning, Rozane Publications, Tehran, 1999.

[2] Pirnia, Muhammad karim, Cognitive of Iranian architecture style (sabk shenasi-e-memari-e-Irani), Soroush Danesh Publications, Tehran, 2007.

[3] Mollazade, Kazem, \& Muhammadi, Maryam, Schools and religious buildings (Madares va bana haye mazhabi), Sura Mehr Publications, Tehran, 2003.

[4] Haji Qasemi, Kambiz, Encyclopedia of schools (Ganjnameh Madares), Cultural Heritage Organization Publications, Tehran, 2001.

[5] Wilber, N. Donald, The Islamic Architecture of Iran and Turan: The Timurid Period, Cultural Heritage Organization Publications, Tehran, 1996.

[6] O'Kane, Bernard, Timurid Architecture in Khurasan (Islamic art and architecture), Islamic Research Foundation Publications, Tehran, 1989.

[7] Sami Azar, Alireza, History of Changes in Iranian schools (Tarikh-e tahavvolat-e madares dar Iran), Renovate and Equip Schools Organization Publications, Tehran, 1998.

[8] Soltanzadeh, Hussein, Iranian school history from ancient times to the establishment of Dar-Al-fonon, Agah Publications, Tehran, 1986.

[9] Blair, Sheila, \& Bloom, Jonathan, Islamic art and architecture (12501800), Samt Publications, Tehran, 2013.

[10] Godard, Andre, Art of Iran (Assar-e Iran), Astan-e Qods Publications, 1936.

[11] Navaii, Abd-Al- Hussein \& Ghaffari Fard, Abbas, History of political, social, economic and cultural Iran during the Safavid (Tatikh-e tahavvolate Iran dar dowran-e Safavi), Samt Publications, Tehran, 2003.

[12] Chardin, Jean, A journey to Persia (in the mid-17th century), Amir Kabir Publications, Tehran, 1971.

[13] Kaempfer, Engelbert, Kaempfer's itinerary (Safaname Kaempfer), Kharazmi Publications, Tehran, 1982.

[14] Loti, Pierre, Towards Isfahan (Hacia Isfahan - Viaje Al Corazon de Persia), Eqbal Publications, Tehran, 1904.

[15] Mostowfi, Abdullah, My biography: A Social administrative History of Ghajar period (Sharh-e zendegani-e-man), Hermes Publications, Tehran, 1947.

[16] Browne, Edward, A Year Among the Persians (Yek sal dar mian-e Iranian), Saffar Publications, Tehran, 1893.

[17] Aubin, Eugene, On Iran today (Iran-e emrooz: 1906-7), Tehran, 1984.

[18] Najmi, Nasser, Tehran during King Nasser, Atar Publications, Tehran, 1986.

[19] Brugsch, Heinrich, Journey of the Royal Prussian Embassy to Persia in 1863 (Dar sarzamin-e aftab), Saadi Publications, Tehran, 1996. 